deley, "Spatial Perception Underwater" by Helen E. Ross, and "Vision" by J. N. Lythgoe) on the various problems and limitations to be overcome by a diver's eyes. Inevitably these chapters overlap a good deal and require many mutual cross-references, and one cannot help feeling that the balance of the book might be better had they been combined into one joint section. After this there are admirable chapters, full of information, on "Fish Behaviour" (C. C. Hemmings) and "Botany" (E. A. Drew), and then a complete change of subject to "Archaeology" (Joan du Plat Taylor). Miss Taylor deals not only with wrecks from the bronze age, through classical times and up to quite recent ones, and with the exploration of ancient, now submerged, harbour installations, but also with the new techniques in surveying and excavating which have been evolved in the past decade or so. This fascinating chapter is followed by "Geomorphology" by N. C. Fleming, which covers such topics as sea-bed deposits and their movements, and the development and maintenance of underwater caves, clefts and cliffsinformation of value to geologists, botanists, zoologists and archaeologists. The book concludes with perhaps the most specialized chapter of all, "Microoceanography" by J. D. Woods; this deals mainly with the structure and behaviour of the thermocline off Malta, studied by the release of dyes. This information is not only interesting in itself, but will also be of help to physical oceanographers and planktologists and to divers themselves as underwater animals.

Before concluding, I have two small bones to pick. First, in case after case a graph would have been made more intelligible to the non-specialist (and few if any readers will be specialists in all the many fields covered by this book) if the legends had been longer and more explanatory. Secondly, I take issue with Dr Lythgoe over his summary dismissal (p. 112) of the Secchi disk because its "measurements cannot be interpreted in physical terms". Why on earth should they be? Surely, the insistence that scientific information is of little or no value unless it can be expressed in precise mathematical terms is becoming a form of idolatry. The Secchi disk is simple, cheap and easy to use, and its readings do give consistent information of biological significance ; for example, whether in the English Channel or on the tropical coast of Queensland a Secchi disk reading will coincide closely with the maximum daylight concentration of zooplankton. This is of real practical importance; if Alain Bombard, on his heroic crossing of the Atlantic in a rubber dinghy, had been able to use a Secchi disk, he could have caught far more fresh food than he did.
Now to sum up: this book is a splendid summary, as of early 1969, of diving science in its early years; no serious diver can afford to be ignorant of it. But all the scientific fields explored in the book are now being ploughed and sown, and they will soon be cropped. In ten or twenty years' time a single volume on "Underwater Science" will almost certainly be impracticable - at least four books will be needed-but in the meantime let us be grateful to editors Lythgoe and Woods for such an admirable introduction.

John S. Colman

\section{Development and Genes}

Developmental Genetics. By Clement L. Markert and H. Ursprung. Pp. 214. (Prentice-Hall: Englewood Cliffs, New Jersey, November 1971.) \$6.95 cloth; $\$ 3.50$ paper.

WE do not know how genes control development. Consequently, the subject is attractive to researchers (and to students), and a relevant paper is published daily and a new review every quarter, or so it seems. It is not a propitious time for textbook writers, and most have been content to deal with only parts of the subject. So Markert and Ursprung's text has been awaited with interest because it promised to survey the whole field and to fill this gap in the literature. Sad to say, it does not come up to expectations. It is out of date (the only 1970 reference is to a collection of earlier papers-and some quoted material is not referenced at all), it is curiously uncertain about its readership and wavers between brief Scientific American-type popularization and detailed technicalities, it is poorly written and often lapses into laboratory jargon, and it is sometimes so inadequate as to be misleading. Teachers, subject to the pressure of undergraduate interest, will still have to work hard preparing supplementary reading lists; and graduate students will find the book useful only as a general introduction.

The weakness of the book is that it tries to do too much in too little space. The first three chapters scan the molecular biology of early amphibian and sea urchin development, as shown by RNA and protein synthesis, respectively; and molecular biology is taken up again in chapter 7 which deals with translational and epigenetic control mechanisms (erythroid and lens development). In between, we have a fairly detailed survey of the authors' work on lactic dehydrogenase as an instance of differential gene function; a discussion of the operon concept and the lack of evidence for operator and regulator genes in eukaryotes; a little about posi- tion-effect variegation, $X$-inactivation, the effects of hormones (hydrocortisone), and a whole chapter on chromosomal differentiation, including puffing of salivary gland chromosomes and lamp-brush chromosomes. The tissue-specific puffs diagrammed in Fig. 6.3 have not been found in recent work, it may be noted.

The remainder of the text is even more of a "sampler": nucleocytoplasmic interactions (nuclear transplants, cell hybridization, maternal effects-with an error in Fig. 8.11); gene interactions (melanocytes); phenocopies; determination and transdetermination; and regeneration. The penultimate chapter tries to compress the developmental aspects of cancer into half-a-dozen pages; and, following Sonneborn, the last chapter asks: "Omnis embryo e DNA?", but not very seriously.

Genetic manipulation has long been used for the study of metabolism, and this aspect of the subject is rightly stressed. But the crucial questions lie within a narrower area with respect to development, and they have a different character: they concern the coordinated activation and inactivation of batteries of genes, and the mechanisms which regulate this switching in the orderly sequence of normal development. The models we now have for this were proposed after the book was written, but none of them accommodates even all the phenomena which the authors summarize. Since the text does emphasize many of the relevant questions, readers may be encouraged to provide their own answers without the prejudice imposed by implausible models. When we have better theories it will be possible to write a more concise book, and to formulate the problems more exactly. JAMES H. SANG

\section{Cell Membranes}

Biomembranes. Vol. 1. Edited by Lionel A. Manson. Pp. xiv +293. (Plenum: New York and London, 1971.) $\$ 21.84$.

Cell Membranes. Edited by Goetz W. Ritcher and Dante G. Scarpelli. Pp. ix +180 . (Williams and Wilkins: Baltimore, 1971. Distributed in the UK by Churchill Livingstone, Edinburgh.) £7.50.

BoTH these latest additions to the literature on cell membranes had their origins in conferences and, although both contain much of interest to workers in this field, their aims are different. Biomembranes is the first volume in a new series to be issued at least once a year, its aim being the "creation of a forum for the lucid exposition of critically 